\title{
OCCUPATIONAL HEALTH AND SAFETY MANAGEMENT IN TERMS OF SPECIAL EMPLOYEE NEEDS - CASE STUDY
}

doi: $10.2478 /$ czoto-2021-0006

Date of submission of the article to the Editor: 29/12/2020

Date of acceptance of the article by the Editor: 02/02/2021

\section{Marta Niciejewska ${ }^{1}$ - orcid id: 0000-0002-9530-3455}

${ }^{1}$ Czestochowa University of Technology - Poland

\begin{abstract}
Every employer is responsible for ensuring safe and hygienic working conditions. According to the Labor Code and the relevant regulations, the elements of safe and hygienic working conditions in each enterprise are very similar. Differences arise when a specific industry or special psychophysical needs of an employee are taking into consideration. There is a specific group of employees for whom the working conditions organized by the employer in terms of occupational health and safety differ from the average working conditions. In the paper the needs, limitations and psychophysical possibilities of professionally active employees with sensory integration disorders are analyzed. In this purpose the direct interview with elements of open observation was used as the research method. The results presented in this paper are the small part (initial diagnosis) of the large project. Preliminary conclusions confirm the difficulty of adapting employees with sensory integration disorders to a universal work environment and the great need to organize special working conditions for them.
\end{abstract}

Keywords: sensory integration disorders, work safety, health protection, psychophysical limitations, special psychophysical needs.

\section{SHAPING OF THE SAFE AND HYGIENIC WORKING CONDITIONS}

Providing employees with safe and hygienic working conditions is the primary responsibility of the employer. It is an undeniable fact resulting from both legal regulations and ethical standards. Shaping safe and hygienic, as well as accident-free working conditions applies to buildings, workplaces, tools, machines and devices (Klimecka-Tatar and Niciejewska, 2016; Niciejewska and Kiriliuk, 2020; Ulewicz et al., 2015; Woźny, 2020). The employee's safety at work is also determined by contact with physical factors of the work environment, such as noise, microclimate, lighting or dust, as well as biological, chemical and psychophysical factors (Kapustka, et al., 2020; Lewandowski and Górska, 2016; Niciejewska and Klimecka-Tatar, 2018).

The procedures for shaping safe and hygienic working conditions as well as organizing such working conditions, taking into account the psychophysical needs of the employee, are established on the basis of legal provisions, regulations, standards and principles of ergonomics (EASHW, 2014; EU-OSHA, 2007 and 2020; Kielesińska, 2020; Krynke, 2020). They are generally the same for all employees, or in some cases 
very similar. They are often determined by age, sex or anthropometric features (Niciejewska and Mlakar Kac, 2019). However, there is a group of employees whose psychophysical abilities are limited and the needs are very specific - for example, professionally active people with sensory integration disorders. It is a disorder that most often accompanies people on the autism spectrum (or Asperger's syndrome). In Poland, there are no statistical studies on the number of students and doctoral students with autism spectrum disorders, but according to the information obtained by the Supreme Audit Office (NIK), these people undertake higher education and their problems are noticed. However, there is no information on the number of people with these disorders who attend and graduate from college. After graduation, people with autism or Asperger Syndrome can find employment in the so-called open labor market. Social research shows that with appropriate support, it is possible for people who have no intellectual deficits to achieve a significant level of independence. However, the employment rate of people with these disorders in Poland is lower than one percent, while in Western European countries it is even over a dozen percent (Supreme Chamber of Control, 2020).

At the end of 2014, the Central Institute for Labor Protection - National Research Institute in Warsaw developed and published "Framework guidelines for the design of facilities, rooms and adaptation of workstations for disabled people with specific needs". This study also includes guidelines for professionally active people on the autism spectrum (including those with sensory integration disorders). However, this section of the guidelines is not intended to be exhaustive. As already mentioned, the professional activity of people with an autism spectrum disorder accompanied by sensory integration disorders is below 1\% in Poland (Supreme Chamber of Control, 2020).

Also, research on the needs, possibilities and psychophysical limitations in the work environment of such people is strongly limited. The sources of such restrictions should be seen, among others, in some of the potential research entities (employees with sensory integration disorders), difficulties in establishing direct contact with such employees (often also verbally), ethical reasons and those resulting, for example, from the General Data Protection Regulation (GDPR).

In order to understand what problems an employee with sensory integration disorders has on a daily basis, it is necessary to explain what they are. Well, these disorders, also called dysfunctions, occur when the nervous system improperly organizes sensory stimuli (Martinez et al., 2020). The dysfunctions are not related to damage to the sense organs, e.g. with hearing loss or myopia (then it would be of some type or degree of disability). Sensory integration dysfunctions refer to abnormalities in the processing of sensory stimuli within the following systems: sensory (tactile and proprioceptive), vestibular, auditory, visual, olfactory and gustatory. Symptoms of sensory integration dysfunction are most often manifested by the following features (Isaacs and Riordan, 2020):

- increased or decreased sensitivity to stimuli,

- inappropriate level of attention,

- reduced level of motor coordination,

- abnormal level of physical activity,

- general behavioral difficulties.

The literature on the subject is poor in information on the topic under consideration. But the information that is available can be taken as the basis for the need for further 
research and analysis. This need results, among others, from the fact that more and more people with disabilities with special needs (including those resulting from sensory integration disorders) are professionally activated. They also often turn out to be very reliable and effective employees.

The shaping and organization of safe working conditions in the aspect of stimuli received by employees can be analyzed through the prism of selected physical factors of the work environment, such as noise and lighting (Bai and Wicaksono, 2020).

These are physical factors that characterize every work environment and can significantly penetrate the area of the employee's sensory integration. General guidelines regarding acceptable or hygienic standards are identical for the average employee. Sometimes the differences are determined by age, gender or psychophysical limitations resulting from disability, disorders or dysfunction.

An employee with sensory integration disorders requires adjustment of the intensity or parameter values of such physical factors (such as the aforementioned noise and lighting). One of the most common harmful factors in the work environment is noise. According to the report published by the European Environment Agency (EEA) entitled 'Noise in Europe - 2020', it is currently estimated that up to 113 million Europeans experience long-term, 24-hour noise levels of at least 55 decibels. In addition, 22 million people are exposed to high levels of rail noise, 4 million to high levels of aircraft noise and less than a million to industrial noise. According to the EEA, in most European countries over 50 percent residents of urban areas are exposed to traffic noise of 55 $\mathrm{dB}$ (or even more) - during the day, evening and night. The highest percentage of urban residents exposed to noise above the acceptable level was recorded in Cyprus (49.2\%) and Switzerland (30.6\%) (Peris, 2020). In Poland, about 11.6 percent of city residents and $5.7 \%$ residents of rural areas, are exposed to road noise exceeding $55 \mathrm{~dB}$ (Spiller, 2020). On the other hand, according to the data of the Central Statistical Office, in 2019, among the factors related to the working environment, the noise posed the greatest risk, about 186.4 thousand people were at risk (58.9\% of all people employed in hazardous conditions related to the work environment; counted as many times as these people were exposed to). The number of workers exposed to noise was more than three times higher than the number of workers exposed to the second most frequent harmful factor - dust (Kazanowska et al., 2020).

Noise has been adopted to denote all undesirable, unpleasant, annoying, burdensome or harmful sounds affecting hearing and other senses and parts of the human body (Augustyńska et al., 2012). The formation of sound is related to momentary changes in air pressure in relation to atmospheric pressure. Sound can also arise in and pass through other media (solids, liquids). During sound formation, pressure changes in the air have a very wide range - from $0.00002 \mathrm{~Pa}$ at the hearing threshold to $63 \mathrm{~Pa}$ at the pain threshold. Therefore, in practice, the term "sound pressure level" expressed in decibels $(\mathrm{dB})$ is used (Engel, 2001). The negative effects of noise can be divided into functional and health. The functional effects include lowering the level of acoustic comfort, difficulties in communication and orientation in the environment. It affects the quality and efficiency of the work performed. Among the health effects, there are: deterioration of psychomotor performance, somatic state and the condition of the hearing organ (Gałusza, 2018). These effects lead to diseases (illnesses).

The most common negative effect of noise on the human body is hearing impairment. Hearing loss related to working conditions is a permanent disability that cannot be cured and has been one of the most common occupational diseases in Poland for many 
years. The non-auditory effect of noise is the body's general response to noise as a stressor. Noise can affect the condition and functions of many internal organs and may contribute to the development of various diseases, e.g. hypertension or neurosis. Research shows that clear disturbances in the physiological functions of the body may occur even after exceeding the level of $75 \mathrm{~dB}$ (Czaja and Bortkiewicz, 2018, Basner et al., 2014). Lower noise levels, in the order of 55 - $75 \mathrm{~dB}$, can cause distraction, hinder work and reduce its efficiency (Niciejewska, 2016). Among the non-hearing effects of noise, one can also distinguish its influence on speech intelligibility and masking of audible safety signals (especially important in the case of hearing impaired people). This not only increases the nuisance of working conditions, but can also cause accidents. In the case of people with mental disabilities resulting from autism spectrum disorders, the following guidelines and recommendations related to noise or verbal signals are formulated (Zawieska, 2014):

- All instructional, information, training materials, etc., concerning safety signals and the organization of work in noise, should be prepared in such a way as to be legible and unambiguous for people with mental disabilities resulting from autism spectrum disorders (e.g. in the form of pictograms), due to on possible problems of these people with understanding the text.

- In the case of people with mental disabilities resulting from autism spectrum disorders, at the same time hypersensitive to sounds, the use of sudden alarms (volume gradation), sharp bells (frequency modulation), sirens should be limited, as they can cause anxiety and panic.

- A person with this type of disability should be assigned an evacuation support. This should be a person who knows the rules of conduct during evacuation and who can safely lead a person with a disability resulting from mental illnesses to the collection point during evacuation.

- It is recommended to extend the sound safety signal with light signaling in the places where the employee may stay (workroom, toilet, break room, etc.).

- It is recommended that, if the degree of disability prevents the correct reception of a safety signal, the introduction of an individual safety system equipped with light or vibration signals.

- It is recommended to develop an internal (separate) communication system for people with disabilities resulting from autism spectrum disorders.

Lighting is also an important physical factor in any work environment - the use of light is essential to highlight places, objects and their surroundings, and applies to all interiors and workplaces. It is an important factor of the work environment, as it determines the visibility of the surroundings and the details of visual work, and thus significantly affects the safety and efficiency of work of all employees. For this reason, lighting is one of the factors determining safety in the work environment and the nuisance of visual tasks (Wolska and Pawlak, 2007). Depending on the type of visual activities performed, lighting should be provided by (Koradecka, 2009):

- appropriate conditions for performing visual tasks,

- visual comfort where employees feel good.

Pursuant to the ordinance of the Minister of Labor and Social Policy on general health and safety regulations, the employer is obliged to provide electric lighting with parameters compliant with Polish Standards. The normative requirements apply to the lighting of the room and workplace, as well as other parts of the building used by the 
employee (Rączkowski, 2020). At workplaces located indoors, the following lighting parameters are assessed (Pawlak et al., 2019):

- illuminance,

- lighting uniformity,

- color rendering (color rendering index),

- light color (color temperature),

- glare,

- flicker, ripple and strobe effect.

In the case of people with disabilities resulting from autism spectrum disorders who are hypersensitive to light (sensory integration disorder), direct and reflected glare, also from windows, as well as light ripple and flicker should be limited. In the case of using fluorescent lamps, electronic ignition systems should be used in order to eliminate flickering light and the strobe effect (Zawieska, 2014).

As a result of the framework guidelines that were developed by the Central Institute of Labor, many proposals for solutions to the problem in question were created. Examples of good practices have been developed on the basis of analyses of real workplaces conducted as part of expert opinions. The basis is also a review of the literature and research on the usefulness of such devices supporting the work of people with disabilities, e.g. a rehabilitation chair, a device enabling wireless computer control, a keyboard for people with one functional upper limb, a device enabling control and communication with a computer by means of eyelid or head movements, keyboard for typing with head or mouth movements etc. Each of the presented examples contains information about the type of disability the presented solution relates to. The following types of disability were included (Bartuzi et al., 2014):

- the movement system,

- eyesight (blind and partially sighted people),

- hearing (deaf and hard of hearing people),

- resulting from mental illnesses,

- resulting from autism spectrum disorders,

- intellectual,

- systemic (e.g. resulting from diseases of the circulatory, respiratory, nervous, digestive, urogenital systems; people suffering from epilepsy).

The proposals of organizing safe and hygienic working conditions for people with disabilities with special needs, who are professionally active, can be a source of information and guidance for all employers who employ workers with various disorders, dysfunctions and special needs.

\section{METHODOLOGY}

The study was conducted in an enterprise (supported employment enterprise) located in the Silesian Voivodeship in Poland. People with various types and degrees of disability work in this enterprise. Among them, there are three adults on the autism spectrum who have a mild disability certificate. These people are employed as a cook, waiter and caretaker. All three employees agreed to conduct a direct interview enriched by observation. The study was conducted outside the company's, in places suggested by their legal guardians. The observation of the work environment was carried out in the place of professional activity, but without the participation of the employees. The face-to-face interview was conducted on the basis of previously prepared issues 
concerning factors that are negatively perceived by the surveyed employees and concern especially areas related to sensory integration. The interview was conducted in the presence of guardians and the results were consulted with the professional activity coordinator of all three employees, who has experience and competence in sensory therapy.

\section{RESULTS AND DISCUSSION}

As a result of the research, a lot of input information was obtained, which can be a source of further research, e.g. related to the design of specific solutions that would support the professional activity of people with sensory integration disorders.

The surveyed employees answered a few questions related to their work environment (technical point of view), made the characteristics of the workplace and the tasks they perform during the day. In general, the work of a cook, waiter and caretaker in the analyzed cases does not differ from the work of an average employee in these positions. Only the analysis of physical factors - such as noise, lighting, microclimate and psychosocial factors shows significant differences. The surveyed employees are people on the autism spectrum, accompanied by sensory integration disorders. These disorders are similar but of different intensity.

The cook indicated, as the biggest problem, a direct (close) contact with another person. However, there is no problem with accepting tastes and smells. Worker smell and taste buds are more sensitive than the average person, which is considered as an asset in this work. Moreover (in this case), the body accepts the high temperatures that are part of the cook's job. The hearing organ of a chef is sensitive and does not accept too high noise levels. High tones are irritating. Therefore, no audible signaling devices (e.g. informing about an order) are used in the kitchen. All information is recorded as text information by the waiter and displayed on the kitchen monitor. The size of the letters and the font color are adapted to the needs of the cook. The font size is at least 18 points and is black on a yellow background. This contrast was chosen by an employee. It fulfills its task, e.g. in peripheral vision, which is most often used by people on the autism spectrum. In a healthy person, the dominant form of visual observation is central looking. Peripheral vision or indirect vision is vision that occurs beyond the point of fixation, i.e. away from the center of vision. For people on the autism spectrum, this type of vision requires less effort and is often more acceptable (not stressful).

An employee working as a waiter also has sensory integration disorders. They mainly concern the sensitivity to light (too high intensity and the phenomenon of glare). For this reason, the café has roller blinds that reduce the penetration of daylight. In the afternoon, on the other hand, warm lighting is preferred in the café, focused directly on the table (hanging lamps slightly above the table, acting as spot lighting). General lighting is designed in the form of wall halogen lamps, which do not directly penetrate the eyes of people in the room, but fulfil their role in terms of effective vision.

A person employed as a caretaker also has sensory integration disorders. An employee in this position primarily performs the functions of facility security - supervision over people who enter the plant. This position is of an administrative and office nature, and work in this position is supported by the coordinator. The employee is equipped with a monitor, which sees people entering the plant. It is the responsibility of the person entering the facility to present the identity and reason for the visit. Pre-arranged visits are checked with an identity card or other document (it is shown to the camera at the entrance, at which there is also a sound signal in the form of a gate panel). Unplanned 
visits are consulted by the caretaker with the coordinator by phone or by text message. The surveyed employee points to direct contact with another human being the greatest problem with regard to dysfunctions related to sensory integration, resulting mainly from the lack of the ability to quickly talk and interact directly. For this reason, the employer developed the aforementioned system of checking people entering and leaving, supported by the coordinator's telephone assistance.

Observations of the work environment of the surveyed people with impaired sensory integration of professionally active people confirmed the purposefulness and usefulness of the designed changes in the elements of the work environment, which caused the employees a problem in the functioning and performance of their work. The changes have been designed in a correct and effective manner and do not threaten the sense of safety and health of employees.

The obtained results are only the beginning of the planned research work on the presented problem on a larger scale. The obtained information confirms a large research gap and indicates the need to create a management system and organization of the work environment of people with special psychophysical needs (including people with sensory integration disorders), who are increasingly (although in Poland it is still a very rare phenomenon) professionally activated in different forms of work and different organizations.

\section{SUMMARY AND CONCLUSION}

Shaping safe and hygienic working conditions by the employer is a fundamental issue in the effective and quality performance of employee tasks. Recently, people with physical and intellectual disabilities have been activated. A specific group (although not yet fully understood), which is slowly starting to become professionally active, are people on the autism spectrum, characterized by impaired sensory integration. All social programs, which are designed to activate such people professionally, should first take into account the dysfunctions of such people in the sphere of sensory integration. Due to a poorly designed work environment, such people may not undertake any activity, because it will be blocked by the lack of acceptance by the organism of intensities, values or properties, e.g. physical factors of the working environment, such as lighting or noise. Of course, there are more such areas, but the two mentioned factors occur in every work environment and, additionally, they are the factors that most often make sensory integration difficult in this group of people.

The paper presents only three cases in which the physical factors of the work environment determine employee activity and influence the effective performance of tasks. It should be noted that the introduced changes did not impose huge financial costs on the employer. In these cases, the employer's commitment, understanding the problem and the willingness to professionally activate people who were at risk of social and professional exclusion were of fundamental importance. There is a great need to create a system that would support people on the autism spectrum, who additionally have sensory integration disorders in undertaking delusional activity. This is a group of people who, to a large extent, are at risk of social and professional exclusion due to the lack of the aforementioned system, but also the existing social barriers, manifested, for example, by the fears and fears of potential employers resulting primarily from the lack of knowledge and system support. 


\section{References}

Augustyńska, D., Pleban, D., Radosz, J., 2012. Zagrożenia hałasem na stanowiskach pracy w Polsce I innych krajach Unii Europejskiej, Medycyna Pracy, 63, 689-700.

Baia, X., Wicaksono, H., 2020. How Relevant Are Environmental Factors in The Ergonomic Performance Assessments? Procedia Manufacturing, 52, 325-330.

Bartuzi, P., 2014. Projektowanie obiektów, pomieszczeń oraz przystosowanie stanowisk pracy dla osób niepełnosprawnych o specyficznych potrzebach - dobre praktyki, Wyd. CIOP-PIB, Warszawa.

Basner, M., Babisch, W., Davis, A., 2014. Auditory and non-auditory effects of noise on health, Lancet, 383, 1325-1332.

Czaja, N., Bortkiewicz, A., 2018. Pozasłuchowe skutki działania hałasu ze szczególnym uwzględnieniem chorób układu krążenia, Forum Medycyny Rodzinnej, 12, 41-49.

Engel, Z., 2001. Ochrona środowiska przed drganiami $i$ hałasem, Wydawnictwo Naukowe PWN, Warszawa.

EU-OSHA, 2007, FACTS71, https://osha.europa.eu/pl/publications/factsheet-71introduction-work-related-musculoskeletal-disorders/view (15.12.2020).

EU-OSHA, 2020. https://osha.europa.eu/pl/publications/risk-assessmentmusculoskeletal-disorders-msds-0/view (24.12.2020).

European Agency for Safety and Health at Work, 2014. Existing and new occupational hazards, Raport, http//.osha.europa.eu// (26.12.2020).

Gałusza, M., 2018. Poradnik służby BHP, Wyd. Tarbonus. Kraków-Tarnobrzeg.

Isaacs, D., Riordan, H., 2020. Sensory hypersensitivity in Tourette syndrome: A review, Brain and Development, 42, 627-638.

Kapustka, K., Ziegmann, G., Klimecka-Tatar, D., Ostrega, M. 2020. Identification of health risks from harmful chemical agents-review concerning bisphenol $A$ in workplace, Production Engineering Archives 26 (2), 45-49. DOI: 10.30657/pea.2020.26.10

Kazanowska, D., Kazimierowska-Wasiołek, M., Pragacz, M., 2020. Warunki pracy w 2019 roku, Główny Urząd Statystyczny, Warszawa, Gdańsk.

Kielesińska, A. 2020. Safety of Imported Machines - Selected Issues in the Context of Polish (UE) Regulation, System Safety: Human - Technical Facility - Environment, 2/1, 174-182, DOI: 10.2478/czoto-2020-0021

Klimecka-Tatar, D., Niciejewska, M., 2016. The OSH management system in the "smallsized" production company, Production Engineering Archives,13/4, 49-52. DOI: 10.30657/pea.2016.13.11

Koradecka, D., 2009. Bezpieczeństwo I higiena pracy, Wyd. CIOP-PIB, Warszawa.

Krynke, M. 2020. Risk management in the process of personnel allocation to jobs. System Safety: Human - Technical Facility - Environment, 2/1, 82-90, DOI: 10.2478/czoto-2020-0011

Lang, R., O'Reilly M., Healy O., Rispoli M., Lydon H., Streusand W., Davis T., Kang S., Sigafoos J., Lancioni G., Didden R., Giesbers S., 2012. Sensory integration therapy for autism spectrum disorders: A systematic review, Research in Autism Spectrum Disorders, 6, 1004-1018.

Lewandowski, J., Górska, E., 2016, Zarzadzanie i organizacja środowiska pracy, Oficyna Wydawnicza Politechniki Warszawskiej, Polska-Warszawa.

Martínez, K., Martínez-García, M., Marcos-Vidal, L., Janssen, J., Castellanos, F., Pretus, C., Villarroya, O., Pina-Camacho, L., Díaz-Caneja, M., Parellada, M., Arango, C., Desco, M., Sepulcre, J., Carmona, S., 2020. Sensory-to-Cognitive 
Systems Integration Is Associated With Clinical Severity in Autism Spectrum Disorder, Journal of the American Academy of Child \& Adolescent Psychiatry, 59, 422-433.

Najwyższa Izba Kontroli, 2020. https://www.nik.gov.pl/aktualnosci/wsparcie-osob-zautyzmem-i-zespolem-aspergera.html (acces: 6.06.2020).

Niciejewska, M., 2016. Wpływ hałasu impulsowego na zdrowie człowieka $w$ aspekcie zagrożeń zawodowych, Teoria i praktyka w zarządzaniu produkcją i usługami (red.) PALISZKIEWICZ, J., INGALDI, M., Oficyna Wydawnicza Stowarzyszenia Menedżerów Jakości i Produkcji, Polska-Częstochowa.

Niciejewska, M., Mlakar Kac, S., 2019, The Work Environment Management in the Aspect of the Safety Shaping at the Administration and Office Workplace, System Safety: Human - Technical Facility - Environment (red.) ULEWICZ Robert, NIKOLIC Ruzica R., 7th International Conference System Safety: Human - Technical Facility - Environment (CzOTO 2018), Zakopane, Polska. 205-210.

Niciejewska, M., Kiriliuk, O. 2020. Occupational health and safety management in "small size" enterprises, with particular emphasis on hazards identification. Production Engineering Archives, 26/ 4, 195-201. DOI: 10.30657/pea.2020.26.34

Niciejewska, M., Klimecka-Tatar, D., 2018. Health problems among employees in small enterprises as a result of improper OHS management, MATEC Web of Conferences 183, 01012. DOI: 10.1051/matecconf/201818301012

Pawlak, A., Pleban, D., Smagowska, B., Sobolewski, A., 2019. Wytyczne dostosowania środowiska pracy $w$ zakresie hałasu, mikroklimatu i oświetlenia w placówkach medycznych, https://www.ciop.pl/CIOPPortalWAR/file/89408/2020022015827\&2_ G_02_Wytyczne.pdf, data dostępu 10.10.2020.

Peris, E., 2020. Environmental noise in Europe - 2020, EEA Raport, 22, Luxembourg.

Rączkowski, B., 2020, BHP w praktyce, Wydanie XVIII, Wyd. ODDK, Gdańsk.

Spiller, J., 2020. https://www.teraz-srodowisko.pl/aktualnosci/raport-eeazanieczyszczenie-halasem-8465.html, data dostępu 10.10.2020.

Ulewicz, R., Klimecka-Tatar, D., Mazur, M., Niciejewska, M., 2015. Wybrane aspekty zarządzania bezpieczeństwem i higieną pracy, Oficyna Wydawnicza Stowarzyszenia Menedżerów Jakości i Produkcji, Polska-Częstochowa.

Wolska, A., Pawlak, A., 2007. Oświetlenie stanowisk pracy, Wyd. CIOP-PIB, Warszawa.

Woźny, A. 2020. Selected problems of managing work safety - case study, Production Engineering Archives 26(3), 99-103. DOI: 10.30657/pea.2020.26.20

Zawieska, W.M., 2014, Projektowanie obiektów, pomieszczeń oraz przystosowanie stanowisk pracy dla osób niepełnosprawnych o specyficznych potrzebach - ramowe wytyczne, Wyd. CIOP-PIB, Warszawa. 